\title{
An approach to optimize the cycling operation of conventional combined heat and power plants
}

Polina Ivanova,

Ervin Grebesh,

Anna Mutule,

\section{Olegs Linkevics}

Faculty of Power and Electrical Engineering, Riga Technical University, Riga, Latvia

Email:polina-ivanova@inbox.lv, ervins.grebess@gmail.com, amutule@edi.lv, olegs.linkevics@rtu.lv
The implementation of the market mechanism, which includes electricity price fluctuation, and a wide integration of intermittent generation, namely solar PV and wind energy, in energy production have changed the role and operation manner of conventional generation. It is partly or not at all adapted to new running conditions. Therefore, the efficiency and flexibility of conventional generation has to be improved. The numerical approach is developed in the context of combined cycle gas turbine (CCGT) technology to adapt its running conditions to the electricity market mechanism. The developed approach was verified on a case study of the Baltic States (Latvia) examples in a multi-paradigm numerical computing environment MATLab. The obtained results show that the added profit is gained through production of supplementary electricity, and the impact of cycling operation is reduced through the decrease of cycling operation ranges numbers and the substitution of start-up with a less adverse one from a technical and economical point of view. The developed approach can be adapted to various technologies and situations by adding appropriate characteristics and constraints of technology.

Keywords: conventional generation, cycling operation, electricity market, start-up, shutdown

\section{INTRODUCTION}

Combined heat and power (CHP) systems seem to be attractive because they can deliver a variety of energy, environmental, and economic benefits. Moreover, CHP applications produce energy where it is needed, avoid wasted heat, and reduce transmission and distribution network and other energy losses [1,2].

The issue is that the implementation of market mechanisms, large-scale integration of intermitted generation in the energy production process and feed-in tariffs for renewable energy sources have changed [3-6]:
- the conventional generation's running conditions, i.e. the shifting from base load operation to cycling operation. It is an operation in line with availability of intermitted generation or fluctuation of the electricity price instead of heat energy demand. This has led to the efficiency decrease of conventional generation and more frequent trips and outages, because it is partly or not at all adapted to the cycling operation;

- the role of conventional generation, i.e. the secure integration of renewable energy sources in the energy production process and provision of regulation service to the transmission system operator instead of heat energy supply in line 
with its demand. This promotes the mass closing or mothballing of conventional generation due to surplus of generation and in turn threatens the security of energy supply.

In [7], S. Lüdge stated, "The economic situation for conventional power plants is so bad that a lot of them will have to shut down permanently in the coming years and naturally there won't be any new projects within this framework. Flexibility, especially from fossil fuel fired power plants is not only needed but is a success factor for the whole energy turn around."

The flexibilisation of conventional generation is needed not only today, but also within the next decades $[2,7,8]$ :

- To adapt existing generation to new running conditions and provide their efficient, flexible and profitable operation;

- To ensure the secure integration of intermitted generation in the energy production process and to ensure a stable energy system;

- To achieve the goal of European Commission concerning renewable energy sources and energy efficiency.

There are different ways to increase flexibility of conventional generation, which were grouped by authors in [9]. Much attention is paid to transient modes, especially to the start-ups. Firstly, they are adverse from an economical, technical and environmental point of view $[10,11]$. Secondly, they provide the main key to increase flexibility of the production unit. Thirdly, the enhancement of power plant flexibility through the start-ups optimization generally is not a cost-based measure [3].

There are a lot of academic papers where the cycling operation of conventional power plants is optimized taken into account the transient modes (start-up, shutdown, warm state preservation). The papers differ in the rate of transient modes' consideration. For example, in [12] and [13] the objective function of the power plant (profit maximization and minimization of production costs) includes costs of transient modes, but their features (type, time, trajectory, etc.) are omitted. However, there are scientific papers where the significant attention is devoted to the features of transient modes. For instance, in [14-16] the start-ups are considered taking into account the preceding offline time of the unit. It was complicated by limiting the temperature increase and the heating speed
[17], ramping constraints, including start-up, shutdown production trajectory, ramp rate and ramp down constraints [18-20], and the change of thermal stress of the main equipment [21].

The rate of transient mode consideration differs from the content of academic paper. For instance, the consideration of transient modes is important where the CHP operation is srudied in portfolio with intermitted generation $[22,23]$ or where different activities are provided with transient modes to optimise the power plant operation as it is presented in this paper.

The authors developed an approach which optimizes the cycling operation of combined cycle gas turbine technology in line with electricity market conditions, i.e. the recovery of additional profit from added produced electricity and the reduction of cycling operation on the equipment technical resource (reduction of start-ups numbers and change of their type to less adverse) by extending the cycling operation range, i.e. shifting shutdown "forward" and start-up "backward". The developed approach is approbated on the example of Riga CHP-2. It can be used to plan the optimal CHP plant generation scheduling to obtain maximum profit or decrease the effect of cycling operation on equipment technical resource in day-ahead and intra-day markets. Also, it can be used in balancing market to evaluate the possibility of added energy production where energy deficit is observed.

\section{THE DEVELOPED APPROACH}

The presented approach is developed for combined cycle gas turbine technology with the aim to optimize its cycling operation in electricity market conditions. The principle of the approach is usable for other technologies and situations as well. It consists of two models: evaluation model (EM) and optimization model (OM). The EM processes the production data of the power plant and consequently determines the cycling characteristics of the power plant and input for the OM. The OM ensures the extension of the cycling operation range by shifting shutdown "forward" and start-up "backward" and hence the supplementary electricity is produced; the numbers of cycling periods are reduced and start-ups are replaced with less adverse ones.

The input parameters of the EM (Fig. 1) are: produced electrical power $(P)$, heat power $(Q)$ 


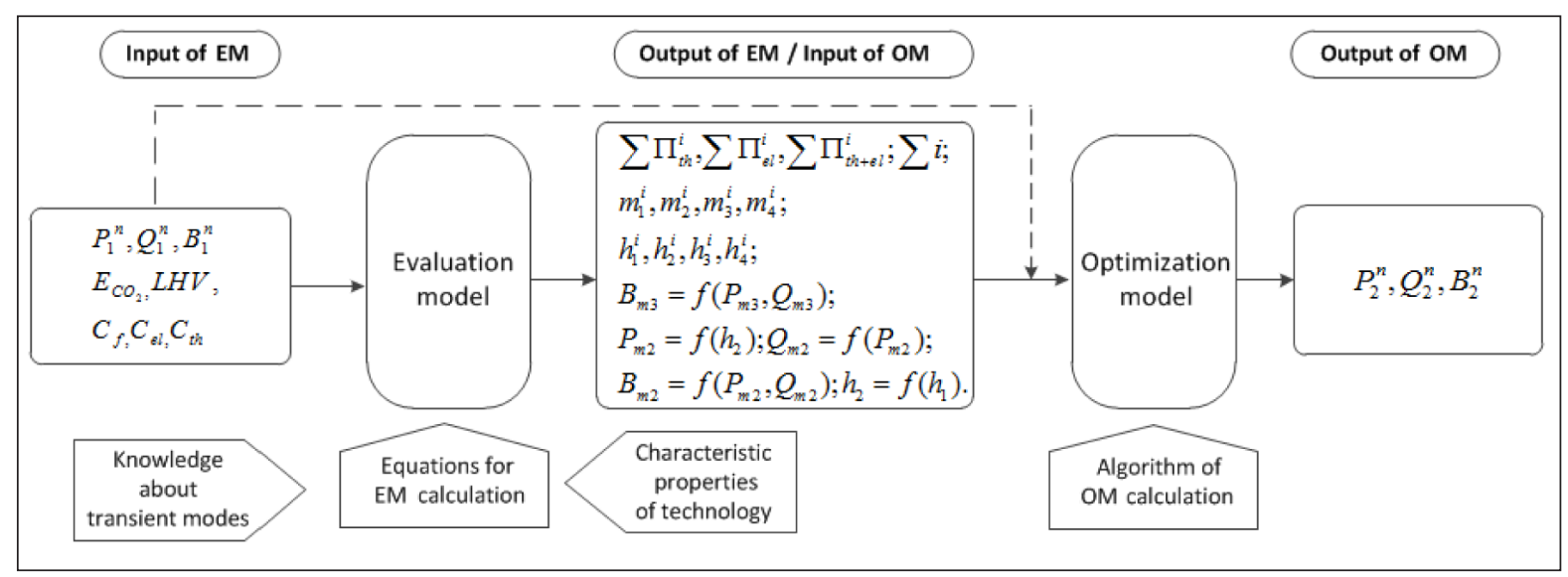

Fig. 1. The flow chart of the developed approach

and fuel consumption $(B)$, price of heat $\left(C_{t h}\right)$, electricity $\left(C_{e l}\right)$ and fuel $\left(C_{f}\right)$, emission factor $\left(E_{\mathrm{CO}_{2}}\right)$ of fuel and its low heat value ( $L H V)$. The equations of the evaluation model are presented in Table 1. The output of the EM provides information about the amount of cycling operation ranges $\left(\sum i\right)$ and its periods $\left(m_{1}, m_{2}, m_{3}, m_{4}\right)$, the duration of transient mode $\left(h_{1}, h_{2}, h_{3}, h_{4}\right)$ and the type of start-ups, the obtained profit from electricity and heat production $\left(\sum \Pi_{t h}, \Sigma \Pi_{e l}, \Sigma \Pi_{t h+e l}\right)$ and characteristics, which are in detail shown in Table 1 and Table 2.

The input of the OM is an output of the EM (obtained characteristics and values of parameters) and the values of EM input parameters describe the initial situation in the optimization model. The calculation of the OM is based on the algorithm presented in Section 2.2. The outputs of the $\mathrm{OM}$ are the new values of electrical power $\left(P_{2}^{n}\right)$, heat power $\left(Q_{2}^{n}\right)$, and consumed fuel $\left(B_{2}^{n}\right)$.

\section{Development of the evaluation model}

The cycling operation range $(i)$ contains these four periods: warm state-preservation $\left(m_{1}\right)$, startup $\left(m_{2}\right)$, operation above technical minimum $\left(m_{3}\right)$, and shutdown $\left(m_{4}\right)$, whose duration is $h_{1}$, $h_{2}, h_{3}, h_{4}$, respectively (Fig. 2 ).

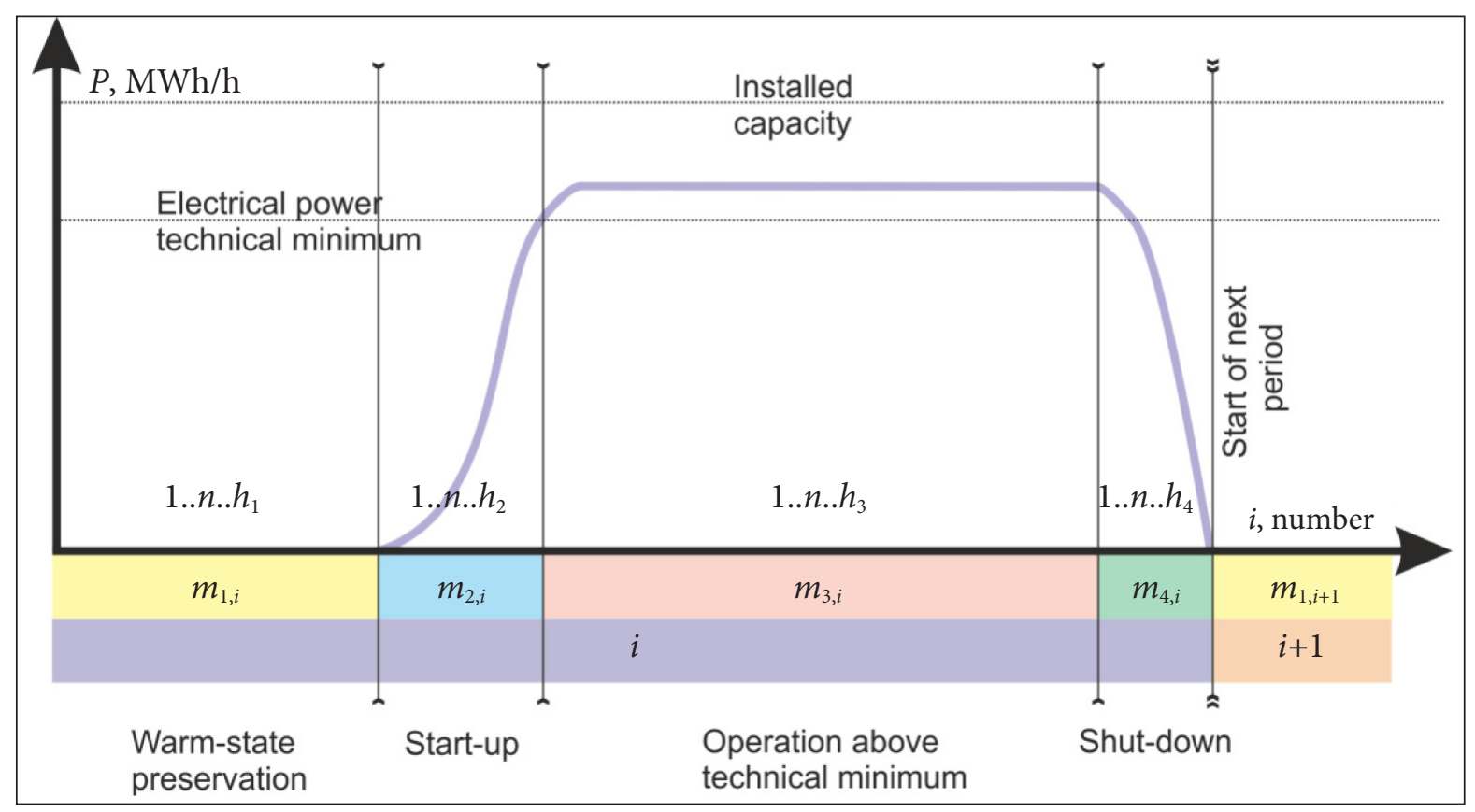

Fig. 2. The model of the cycling operation range (i) 
The duration of $h_{1}$ determines the type of start-up. There are three start-up types: hot (if $\left.h_{1} \leq 12\right)$, warm $\left(12<h_{1} \leq 72\right)$, and cold (if $\left.h_{1}>72\right)$. The duration of warm state preservation $\left(h_{1}\right)$ defines the continuation of start-up $\left(h_{2}\right)$, i.e. for cold start-up $h_{2}>5$ hours, for warm start-up $2<h_{2} \leq 5$ hours, and for hot startup $h_{2} \leq 2$. The changes of electrical power $(P)$, heat power $(Q)$, fuel consumption $(B)$ during the cycling operation range are illustrated in Fig. 3.

The equations (1-9) of the EM (Table 1) are developed based on information in Fig. 2 and previously obtained knowledge about transient modes and characteristic properties of combined cycle gas turbine technology in [24, 25].

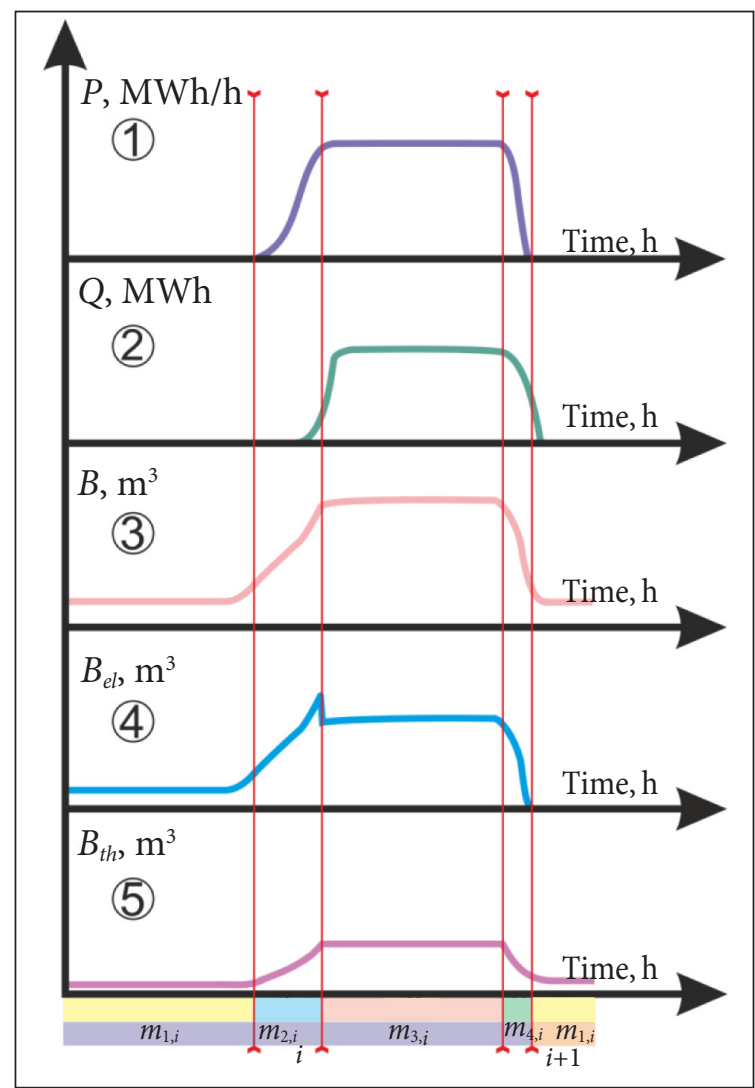

Fig. 3. The schematic change of electricity, heat and fuel during the cycling operation range " $i$ "

\section{Remarks:}

(1) The change of electrical power is taken as a reference point, i.e. the division of the cycling operation range to $m_{1^{\prime}} m_{2^{\prime}} m_{3}$ and $m_{4}$.

(2) Heat power falls behind electrical power in $m_{2}$ and $m_{3}$. At the end of $m_{4}$ and at the beginning of $m_{1, i+1}$ heat power is greater than zero and electrical power is equal to zero. The value of heat power in $m_{1}, i+1$ is shifted to the warm state preservation of a new cycling operation range, i.e. $i+1$.

(3) Fuel is consumed, when the unit is out of operation, to preserve the warm state of the unit. If the outage is too long, then the warm state is not preserved. Also, the total consumed natural gas for electricity and heat production is taken as an input data in a mathematical model of cycling operation range evaluation.

(4) (5) Natural gas for heat and electricity production in $m_{3}$ and $m_{4}$ was calculated by equation (1) and (2), correspondingly. Due to a short duration of $m_{4}$ (less than 30 minutes) the consumption of fuel is calculated for both periods simultaneously. Fuel consumption for heat and electricity production in $m_{1}$ and $m_{2}$ is calculated proportionally to the produced heat and electricity in $m_{1}$ and $m_{2}$. It is done by equations (3-4). The $Q_{m_{1}, i}=Q_{m_{1}, i-1}$ due to the fact that at the end of $m_{4}$ and at the beginning of $m_{1, i+1}$ heat power is greater than zero and electrical power is equal to zero. 
Table 1. Equations of the evaluation model

\begin{tabular}{|c|c|c|c|}
\hline Equation & Unit & Meaning & $\begin{array}{l}\text { Eq. } \\
\text { No. }\end{array}$ \\
\hline$B_{t h_{n, m 3 . .4}}^{i}=\frac{Q_{n, m_{3.4}}^{i}}{0.93 \times L H V}$ & {$\left[\mathrm{~m}^{3} / \mathrm{h}\right]$} & $\begin{array}{l}\text { The consumption of fuel for heat } \\
\text { production in periods: operation } \\
\text { above technical minimum and } \\
\text { shutdown (Coefficient } 0.93 \text { descri- } \\
\text { bes the efficiency of heat producti- } \\
\text { on in cogeneration mode) }\end{array}$ & (1) \\
\hline$B_{e l_{n, m 334}}^{i}=B_{n, m, \ldots 4}^{i}-B_{t h_{n, m 334}}^{i}$ & {$\left[\mathrm{~m}^{3} / \mathrm{h}\right]$} & $\begin{array}{l}\text { The natural gas consumption for } \\
\text { electricity production in periods is: } \\
\text { operation above technical mini- } \\
\text { mum and shutdown }\end{array}$ & (2) \\
\hline$B_{t h_{n, m 1 \ldots} \ldots}^{i}=B_{n, m, \ldots 2}^{i} \times \frac{\sum_{m_{1}}^{m_{2}} \sum_{n=1}^{n=N} Q_{n, m}^{i}}{\sum_{m_{1}}^{m_{2}} \sum_{n=1}^{n=N} P_{n, m}^{i}}$ & {$\left[\mathrm{~m}^{3} / \mathrm{h}\right]$} & $\begin{array}{l}\text { The consumption of natural gas } \\
\text { for heat production in periods: } \\
\text { warm state preservation and start- } \\
\text { up }\end{array}$ & (3) \\
\hline$B_{e l_{n, m 1 \ldots 2}}^{i}=B_{n, m_{1} \ldots 2}^{i}-B_{t h_{n, m 1 \ldots 2}}^{i}$ & {$\left[\mathrm{~m}^{3} / \mathrm{h}\right]$} & $\begin{array}{l}\text { The natural gas consumption } \\
\text { for electricity production, when } \\
\text { cogeneration unit is in warm state } \\
\text { preservation or is started-up }\end{array}$ & (4) \\
\hline$M C_{\text {elavg }}^{i} n, m=\frac{\sum_{m_{1}}^{m_{4}} \sum_{n=1}^{n=N}\left(B_{e_{n, m}}^{i} \times C_{f_{n, m}}^{i}+B_{e_{n, m}}^{i} \times L H V \times E_{C O_{2}} \times C_{C O_{2 n, m}}^{i}\right)}{\sum_{m_{2}}^{m_{4}} \sum_{n=1}^{n=N} P_{n, m}^{i}}$ & [€/MWh] & $\begin{array}{l}\text { The average marginal cost of elec- } \\
\text { tricity per cycling operation range }\end{array}$ & (5) \\
\hline$M C_{t h_{a v g} n, m}^{i}=\frac{\sum_{m_{1}}^{m_{4}} \sum_{n_{1}}^{n}\left(B_{t h_{n, m}}^{i} \times C_{f_{n, m}}^{i}+B_{t h_{n, m}}^{i} \times L H V \times E_{C O_{2}} \times C_{C O_{n_{n, m}}}^{i}\right)}{\sum_{m_{2}}^{m_{4}} \sum_{n_{1}}^{n=N} Q_{n, m}^{i}}$ & [€/MWh] & $\begin{array}{l}\text { The average marginal cost of heat } \\
\text { per cycling operation range }\end{array}$ & (6) \\
\hline$\Pi_{t h}^{i}=\sum_{m_{1}}^{m_{4}} \sum_{n=1}^{n=N}\left(C_{t h_{n, m}}^{i} \times Q_{n, m}^{i}-B_{t h_{n, m}}^{i}\left(C_{f_{n, m}}^{i}+L H V \times E_{C O_{2}} \times C_{C O_{2 n, m}}^{i}\right)\right)$ & {$[€]$} & $\begin{array}{l}\text { The profit of produced heat in } \\
\text { cycling operation ranges per year }\end{array}$ & (7) \\
\hline$\Pi_{e}^{i}=\sum_{m_{1}}^{m_{4}} \sum_{n=1}^{n=N}\left(C_{e_{n, m}}^{i} \times P_{n, m}^{i}-B_{e_{n, m}}^{i}\left(C_{f_{n, m}}^{i}+L H V \times E_{C O_{2}} \times C_{C O_{2_{n, m}}}^{i}\right)\right)$ & {$[€]$} & $\begin{array}{c}\text { The profit of produced electricity } \\
\text { in cycling operation ranges per } \\
\text { year }\end{array}$ & (8) \\
\hline$\Pi^{i}=\Pi_{e}^{i}+\Pi_{t h}^{i}$ & {$[€]$} & $\begin{array}{l}\text { The total profit of heat and electri- } \\
\text { city production in cycling operati- } \\
\text { on ranges per year }\end{array}$ & (9) \\
\hline
\end{tabular}

Figure 4 illustrates the simultaneous change of three parameters: natural gas consumption, heat power, and electrical power. Equation 10 presents the mathematical relation of these parameters; it is used as an input of the OM:

$$
B_{m_{3}}=a_{1} \times P_{m_{3}}+a_{2} \times Q_{m_{3}}+a_{3}\left[\mathrm{~m}^{3}\right]
$$

Table 2 reflects the obtained start-ups characteristics of CCGT technology. They are:
- the duration of start-up from the continuation of warm state preservation $h_{2}=f\left(h_{1}\right)$;

- the consumed fuel for production of electricity and heat $B_{m_{2}}=f\left(P_{m_{2}}, Q_{m_{2}}\right)$ during start-up $\left(m_{2}\right)$;

- the change of electrical power during startup from start-up type $P_{m_{2}}=f\left(h_{2}\right)$;

- the change of heat power from electrical power $Q_{m_{2}}=f\left(P_{m_{2}}\right)$ during start-up $\left(m_{2}\right)$.

The fitness of mathematical relations (Table 2), i.e. coefficient of determination (R-squared) and 


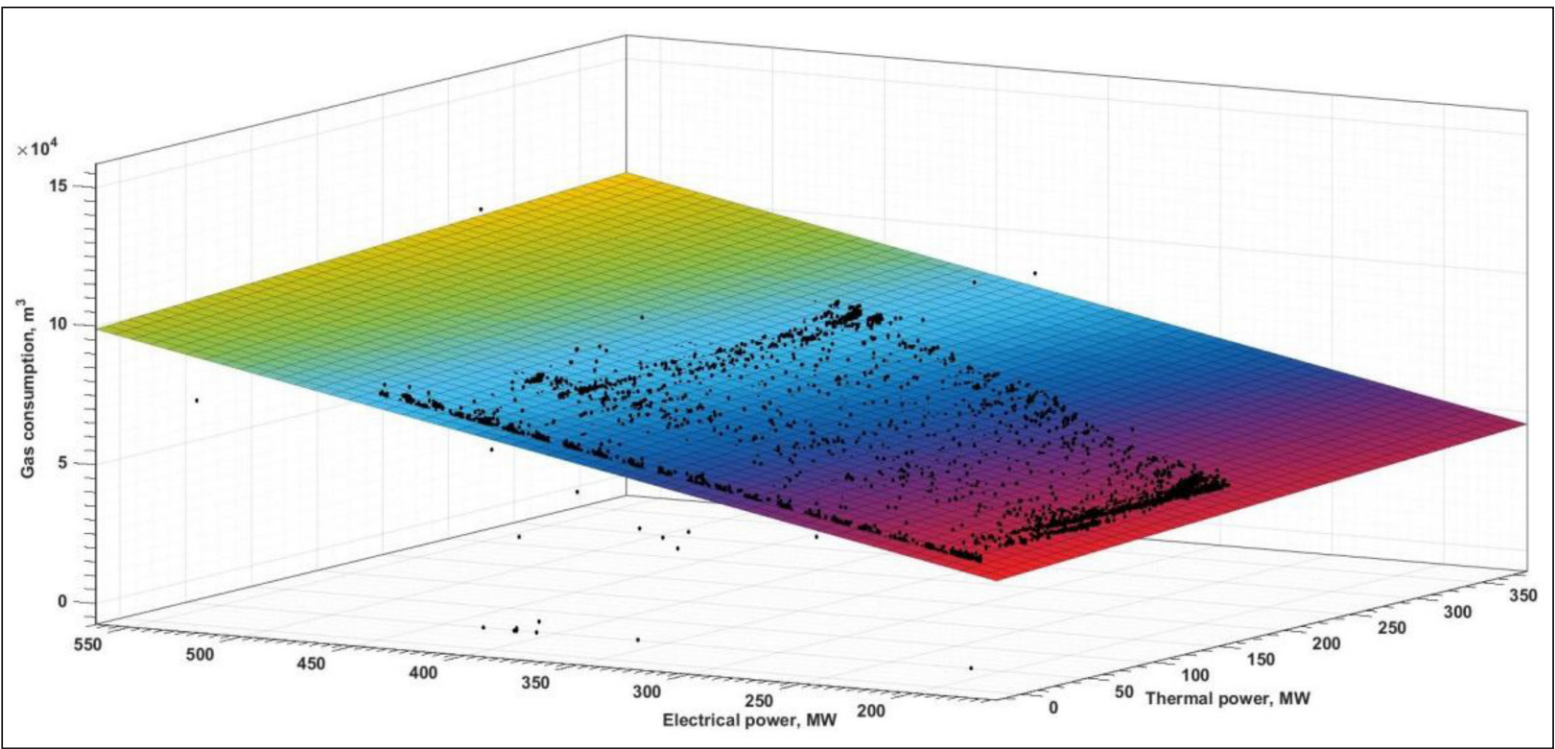

Fig. 4. Natural gas consumption as a function of electrical and heat power

Table 2. Start-up characteristics of CCGT technology

\begin{tabular}{ccc}
\hline Start-up type & Function & Fitness \\
\hline All & $h_{2}=a_{1} \times h_{1}+a_{0}$ & R-square: $0.9904 ;$ RMSE: 0.1757 \\
\hline \multirow{3}{*}{ Cold } & $B_{m_{2}}=b_{1} \times P_{m_{2}}+b_{1}{ }^{\prime} \times Q_{m_{2}}+b_{0}$ & R-square: $0.9655 \&$ RMSE: 1097 \\
\cline { 2 - 3 } & $P_{m_{2}}=c_{2} \times h_{2}{ }^{2}+c_{1} \times h_{2}+c_{0}$ & R-square: $0.9415 ;$ RMSE: 12.67 \\
\cline { 2 - 3 } & $Q_{m_{2}}=d_{3} \times P_{m_{2}}^{3}+d_{2} \times P_{m_{2}}^{2}+d_{1} \times P_{m_{2}}+d_{0}$ & R-square: $0.7916 \&$ RMSE: 11.06 \\
\cline { 2 - 3 } Warm & $B_{m_{2}}=u_{1} \times P_{m_{2}}+u_{1}{ }^{\prime} \times Q_{m_{2}}+u_{0}$ & R-square: $0.9833 \&$ RMSE: 1099 \\
\cline { 2 - 3 } & $P_{m_{2}}=k_{1} \times h_{2}+k_{0}$ & R-square: $0.9393 \&$ RMSE: 13.21 \\
\hline \multirow{3}{*}{ Hot } & $Q_{m_{2}}=I_{2} \times P_{m_{2}}^{2}+l_{1} \times P_{m_{2}}+l_{0}$ & R-square: $0.8364 \&$ RMSE: 9.581 \\
\cline { 2 - 3 } & $B_{m_{2}}=r_{1} \times P_{m_{2}}+r_{1} \times Q_{m_{2}}+r_{0}$ & R-square: $0.9739 \&$ RMSE: 1015 \\
\cline { 2 - 3 } & $P_{m_{2}}=v_{1} \times h_{2}+v_{0}$ & R-square: $0.7361 \&$ RMSE: 19.7 \\
\cline { 2 - 3 } & $Q_{m_{2}}=z_{2} \times P_{m_{2}}^{2}+z_{1} \times P_{m_{2}}+z_{0}$ & R-square: $0.9006 \&$ RMSE: 9.566 \\
\hline
\end{tabular}

root-mean-square error (RMSE), reflects a good correlation among the parameters.

\section{Development of the optimization model}

The proposed principle of the optimization model can be used in day-ahead and intra-day markets to ensure more profitable operation of a thermal power plant. Also, it can be used in balancing market to evaluate the possibility of producing additional energy when power deficit is observed. The information about Nord Pool physical markets can be found in $[26,27]$. The developed optimization model can be integrated in the unit commitment (UC) model to take into consideration the cycling operation of thermal power plants and increase the accuracy of the UC model. If the introduced optimization model is not going to be integrated into the UC model, then additional calculations are needed to check the influence of additionally produced energy on the generation portfolio. In this article, the concept of optimization task (Fig. 5) and its calculation algorithm (Fig. 6) are based on the principles of the Nord Pool intra-day physical market when the UC model results are 
known. The developed approach is verified omitting the fact that additionally produced energy influences other energy sources.

According to the developed approach, the optimization of cycling operation is achieved through the extension of the cycling operation range (Fig. 5). The optimization time interval is limited to 24 hours, i.e. $\sum h_{1,2,3,4}=24$. It is expected to gain added profit from the additionally produced energy in the market and decrease the adverse influence of cycling operation on equipment technical resource through the reduction of startups and change of their types to the less adverse ones. The last is taken for granted without numerical evidence based on literature $[4,11,28,29]$ and know-how.

The situation is variable at the electricity market, for instance, in the first additional hour of operation the profit is $\Pi_{1}>0$, in the second $-\Pi_{2}<0$, but $\Sigma \Pi_{1,2}>0$, because $\Pi_{1}>>\sum \Pi_{1,2}$. In the third added hour the profit is $\Pi_{3}>0$, but $\sum \Pi_{1,2,3}<\Pi_{1}$, because $\Pi_{1}>>\Pi_{3}$. The dilemma rose, i.e. the maximum profit was obtained in the first hour, but the probability to reduce the adverse influence of cycling operation of equipment technical resource is smaller than in the second and third hours. However, the total gain profit for the first and second or for the first, second and third hours is positive, but is less than in the first additional hour. That is why the optimization task can be implemented in two ways: refer to the maximum profit (Optimization No. 1) or refer to the positive profit and reduction of the cycling operation negative impact on equip- ment technical resource by maximizing the hours in operation $(n)$ under condition that gained profit must be positive (Optimization No. 2). It is expressed through the maximization of operation hours $(n)$.

The objective function for Optimization No. 1 is as follows:

$$
\begin{aligned}
& \sum_{i}\left[\sum_{m_{1}}^{m_{4}} \sum_{n=1}^{n=N}\left(C_{e_{n, m}}^{i} \times P_{n, m}^{i}-B_{e_{n, m}}^{i}\left(C_{f_{n, m}}^{i}+L H V \times E_{C O_{2}} \times C_{C O_{2 n, m}}^{i}\right)\right)\right. \\
& \left.+\sum_{m_{1}}^{m_{2}} \sum_{n=1}^{n=N}\left(C_{t h_{n, m}}^{i} \times Q_{n, m}^{i}-B_{t h_{n, m}}^{i}\left(C_{f_{n, m}}^{i}+L H V \times E_{C O_{2}} \times C_{C O_{2 n, m}}^{i}\right)\right)\right] \rightarrow \max \Pi
\end{aligned}
$$

Subject to

$$
\begin{aligned}
& i=1, \ldots, I, i \in Z_{+} \\
& n=1, \ldots, N, n \in Z_{+} \\
& N \leq 24 \\
& \left\{\begin{array}{l}
P=0 \\
Q=0
\end{array} \text { if } m=m_{1}\right. \\
& \left\{\begin{array}{l}
0<P \leq P_{m 2} \quad \text { if } m=m_{2} \\
0<Q \leq Q_{m 2}
\end{array}\right. \\
& \left\{\begin{array}{l}
P^{\min }<P \leq P^{\max } \quad \text { if } m=m_{3}, m_{4} \\
Q^{\min }<Q \leq Q^{\max }
\end{array}\right.
\end{aligned}
$$

The objective function for Optimization No. 2 is as follows:

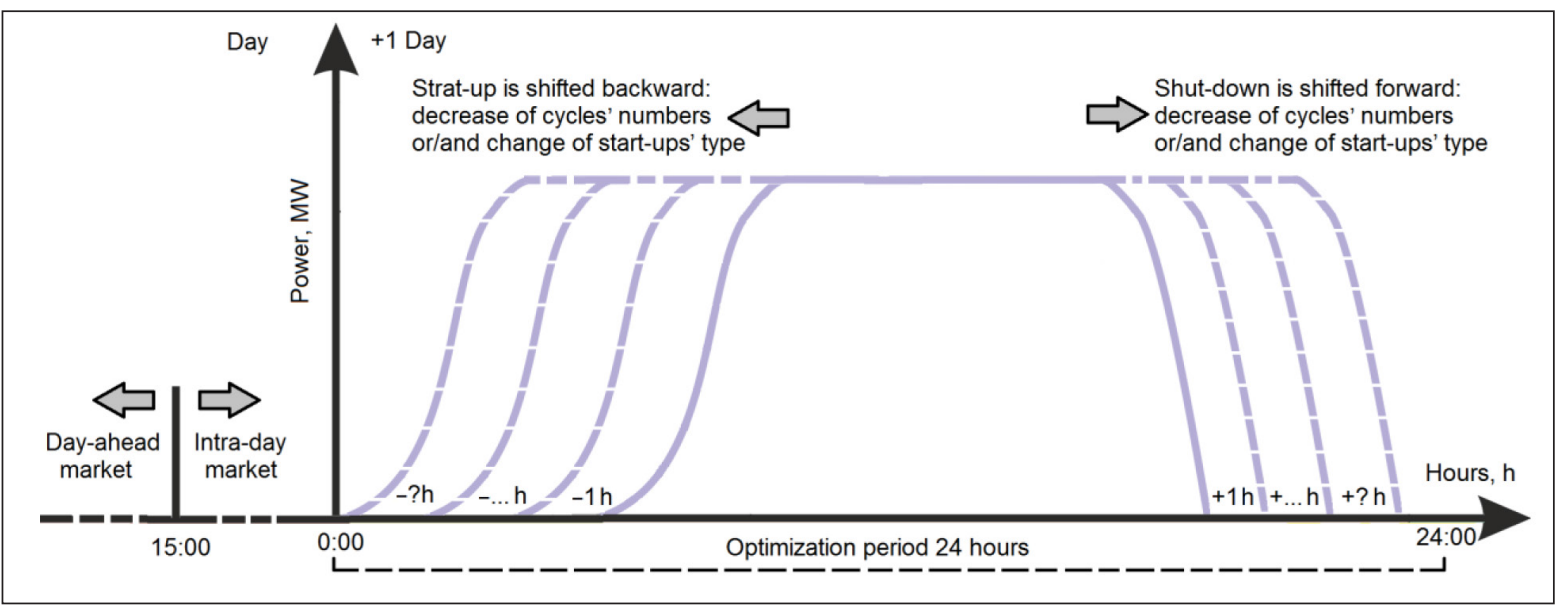

Fig. 5. A classic example of optimization task concept 


$$
\begin{aligned}
& \sum_{i}\left[\sum_{m_{1}}^{m_{4}} \sum_{n=1}^{n=N}\left(C_{e_{n, m}}^{i} \times P_{n, m}^{i}-B_{e_{n, m}}^{i}\left(C_{f_{n, m}}^{i}+L H V \times E_{C O_{2}} \times C_{C O_{2 n, m}}^{i}\right)\right)\right. \\
& \left.+\sum_{m_{1}}^{m_{2}} \sum_{n=1}^{n=N}\left(C_{t h_{n, m}}^{i} \times Q_{n, m}^{i}-B_{t h_{n, m}}^{i}\left(C_{f_{n, m}}^{i}+L H V \times E_{C O_{2}} \times C_{C O_{2 n, m}}^{i}\right)\right)\right] \rightarrow \max \Pi
\end{aligned}
$$

Subject to

$$
\begin{aligned}
& i=1, \ldots, I, i \in Z_{+} \\
& n=1, \ldots, N, n \in Z_{+} \\
& N \leq 24 \\
& \left\{\begin{array}{l}
P=0 \\
Q=0
\end{array} \text { if } m=m_{1}\right. \\
& \left\{\begin{array}{l}
0<P \leq P_{m 2} \quad \text { if } m=m_{2} \\
0<Q \leq Q_{m 2}
\end{array}\right. \\
& \left\{\begin{array}{l}
P^{\min }<P \leq P^{\max } \\
Q^{\min }<Q \leq Q^{\max } \quad \text { if } m=m_{3}, m_{4}
\end{array}\right.
\end{aligned}
$$

$$
\Pi>0, \Pi \in R_{+}
$$

The input of OM algorithm (Fig. 6) is the production data of technologies $(P, Q, B$, etc.) and obtained characteristics in Table 2. Initially, the calculation day is identified in line with Nord Pool market principles (the total number of days is 365/366). After the extension of technology, the working time is calculated for each identified day by shifting shutdown "forward" and start-up "backward" until the optimal solution is achieved in line with Optimization No. 1 and 2. The obtained results are accumulated while the calculations for all days of the year are done. After they are finished, the appropriate solution is found.

\section{CASE STUDY: APPLICATION OF THE DEVELOPED APPROACH IN RIGA CHP-2}

\section{Investigated object: Riga CHP-2}

After Latvia has joint the Nord Pool electricity market in June 2013, the production unit Riga CHP-2 started to operate in line with electricity market conditions. The power plant is in operation if its production costs are less than the electricity price at the market and is stopped if its marginal costs are higher than the electricity price. The Riga CHP-2 power plant is not fully adapted to the cycling modes. Moreover, taken into account the significance of CHP-2 in the Baltic States, the negative consequences may arise, which are described in detail with calculus in [30], if flexibility and efficiency of the cogeneration power plant will not be sustained. That is why Riga CHP-2 has been chosen as an investigated object to verify the developed approach in Section 2 and iprovide recommendations for the CHP-2 plant in line with the developed approach.

Briefly, the CHP-2 power plant is located in Acone, i.e. $28 \mathrm{~km}$ from Riga (the capital of Latvia). It is a base load power plant. CHP-2 consists of two combined cycle gas turbine units, CCGT-2/1 $(P=413 \mathrm{MW}$ and $Q=274 \mathrm{MW})$ and CCGT-2/2 $(P=419 \mathrm{MW}$ and $Q=270 \mathrm{MW})$, and five heat

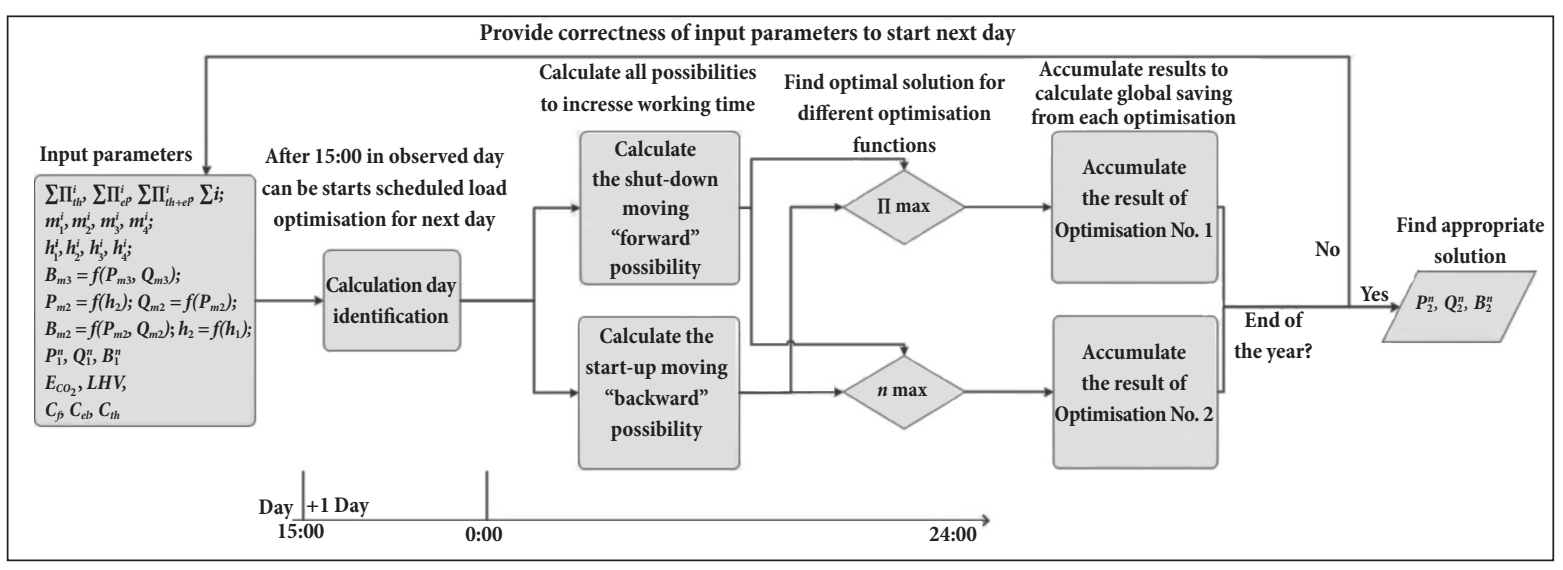

Fig. 6. The algorithm for optimization model calculation 
only boilers $(Q=5 \times 116 \mathrm{MW})$. Natural gas is used as a primary fuel, and diesel as emergency fuel. Cogeneration units (CCGT-2/1 and CCGT-2/2) are identical, that is why further the operation features and developed approach approbation are shown on the example of CCGT-2/1. The cogeneration unit operates in these three modes:

- cogeneration and condensation $\left(P_{\text {cog. \& cond. }}=\right.$ $190-413 \mathrm{MW}$ and $\left.Q_{\text {cog. \& cond. }}=60-180 \mathrm{MW}\right)$;

- pure cogeneration $\left(P_{\text {pure cog. }}=190-413\right.$ and $\left.Q_{\text {pure cog. }}=180-274 \mathrm{MW}\right)$;

- pure condensation $\left(P_{\text {pure cond. }}=190-442 \mathrm{MW}\right.$ and $\left.Q_{\text {pure cond. }}=0 \mathrm{MW}\right)$.

Figure 7 reflects the CCGT-2/1 operation area (modes) and operation statistics for three years (2014-2016). The shifting from efficient modes (pure cogeneration) to inefficient operation conditions (cogeneration and condensing) can be noticed. For example, the operation in pure cogeneration mode was $44.09 \%$ in $2014,1.14 \%$ in 2015 , and $16.88 \%$ in 2016 . In turn, the operation in cogeneration and condensation mode increased from $31.7 \%$ (in 2014) to $48.37 \%$ (in 2016). The running conditions were determined by ambient temperature, electricity price, and natural gas price. The cogeneration unit was operated mainly in pure condensation mode (84\%) in 2015 due to a low heat energy demand, low natural gas price, and high electricity price. How- ever, the pure condensation in 2014 and 2016 was $24.22 \%$ and $34.74 \%$, respectively.

\section{Results of model evaluation}

The CCGT-1 cycling operation range was analysed for 2016 in line with the approach introduced in Section 2.1. There were 57 start-ups or $i$ cycling operation range: 15 hot start-ups, 19 warm start-ups, and 23 cold start-ups.

The cold start-up was 2 times longer than the warm start-up and 4 times longer than the hot start-up. The average duration of the cold start-up was more than 4 hours (Fig. 8).

During the cold start-up, approximately 2 times more natural gas was consumed than for the warm start-up and approximately 3 times more than for the hot start-up. The average consumed natural gas for the cold start-up was $9.8 \times 10^{4} \mathrm{~m}^{3}$ (Fig. 9).

In 2016, the longest cycling operation range was 448 hours, and the shortest 8 hours. The average duration of the cycling operation range was 45 hours (Fig. 10). The maximum values of benefit from electricity and heat realization were $3.2 \times 10^{6} €$ and $175.4 \times 10^{3} €$, respectively. The maximum values of losses from electricity and heat productions were $140 \times 10^{3} €$ and $8.5 \times 10^{3} €$, correspondingly. The profit from electricity and heat realization of CCGT-2/1 was

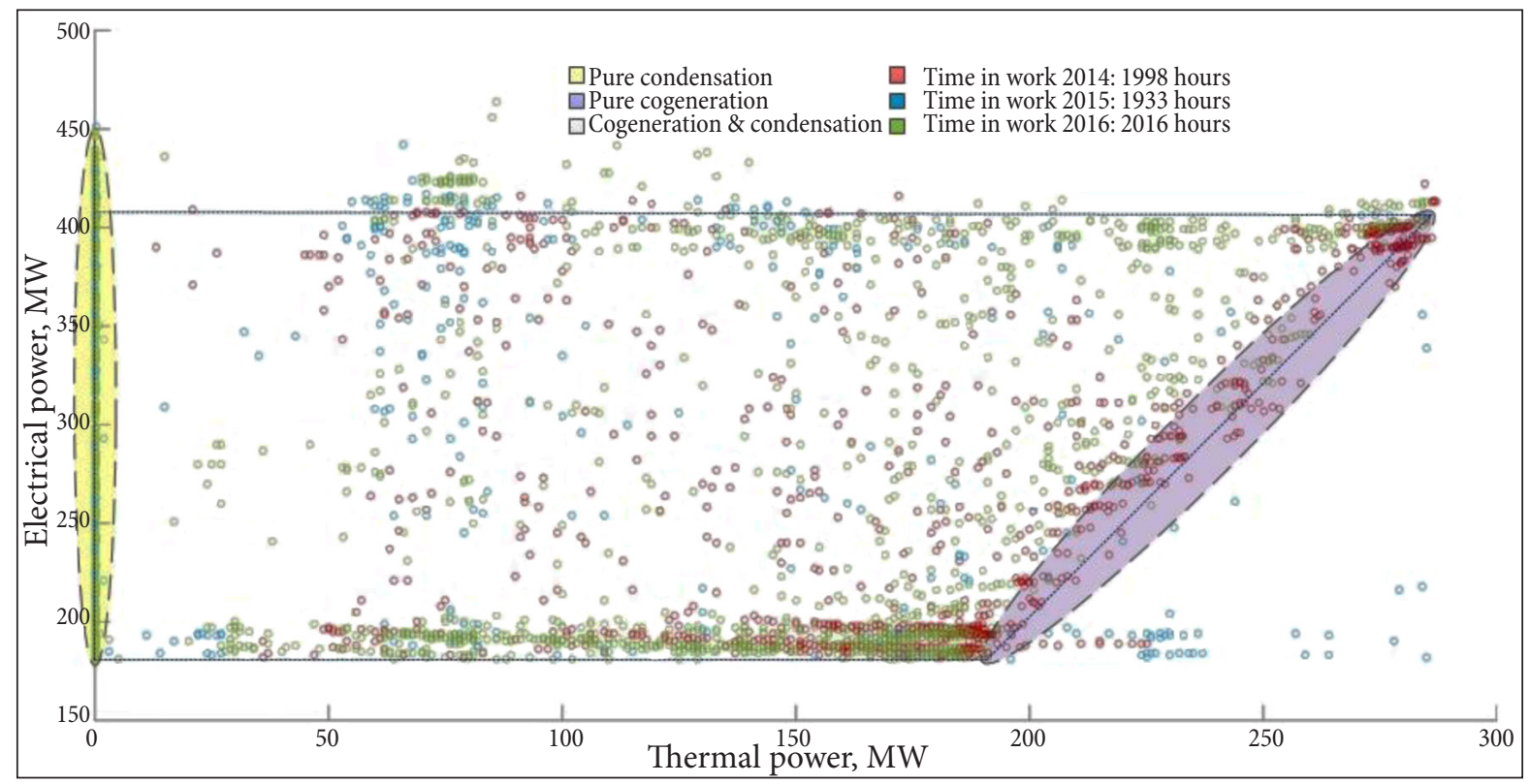

Fig. 7. CCGT-2/1 operation area and operation statistics 


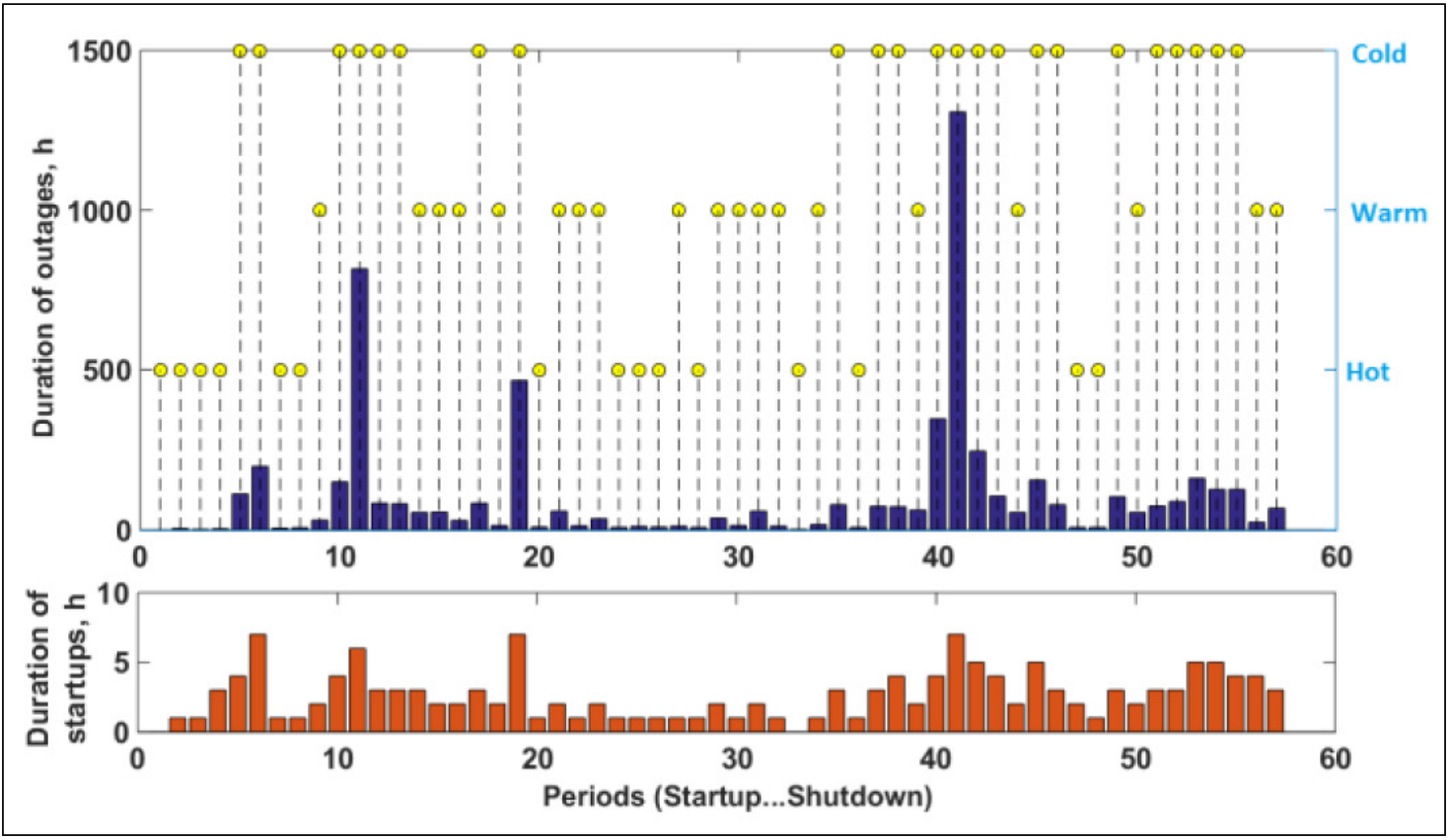

Fig. 8. Types of start-ups, duration of start-ups and outages

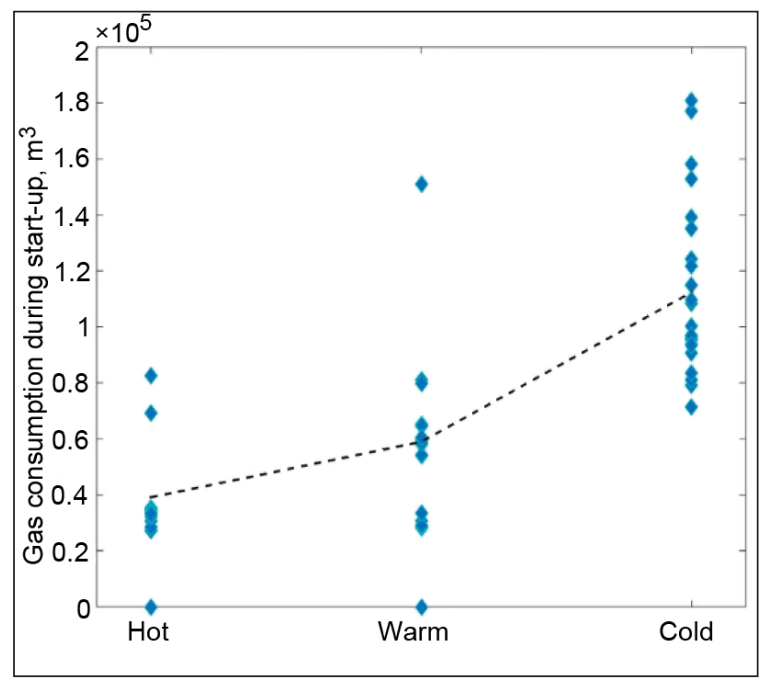

Fig. 9. Gas consumption versus start-up time

$6.0 \times 10^{6} €$ and $400.0 \times 10^{3} €$ per 2016. The obtained results indicate that the realization of electricity provides higher profit for the power plant than the realization of heat energy. The total profit from heat and electricity realization of CCGT-2/1 was $6.4 \times 10^{6} €$ in 2016 .

\section{Results of the optimization model}

Table 3 shows the results of shifting shutdown "forward" and start-up "backward" by extension of the cycling operation range for two optimization tasks: $\Pi \rightarrow \max$ and $n \rightarrow$ max.
The results of Optimization No. 1 demonstrate that the number of operation ranges stays the same, i.e. 57. The amount of the warm start-up and cold start-ups reduced by 4 and 2, respectively, that is why the hot start-ups increased by 6 . The increment of operation hours is 228 hours, and of added profit is $1.42 \mathrm{M} €$. The results of Optimization No. 2 reflect that the number of warm and cold start-ups reduces by 4 and 2, respectively, but hot start-ups increase by 2 due to the reduction of cycling operation from 57 to 53 . The increment of operation hours is 275 hours, and of profit is $1.27 \mathrm{M€}$.

After the results of two optimization tasks had been compared, the authors concluded that Optimization No. 1 ensured a higher profit than Optimization No. 2, i.e. 1.42 $\mathrm{M} €$ and 1.27 M€, respectively. The difference is insignificant, approximately $150 \mathrm{k} €$. In turn, the results of Optimization No. 2 demonstrated the decrease of cycling operation ranges by four cycles, whereas Optimization No. 1 did not. The optimization under condition $n \rightarrow \max$ is preferable.

For instance, Fig. 11 represents a graphical illustration of changes in CCGT-2/1 operation (the probability of start-up and shutdown) before (the dash red and blue line) and after (the solid red and blue line) Optimization No. 2. The red lines describe the duration of outages, and blue lines characterise the duration of 


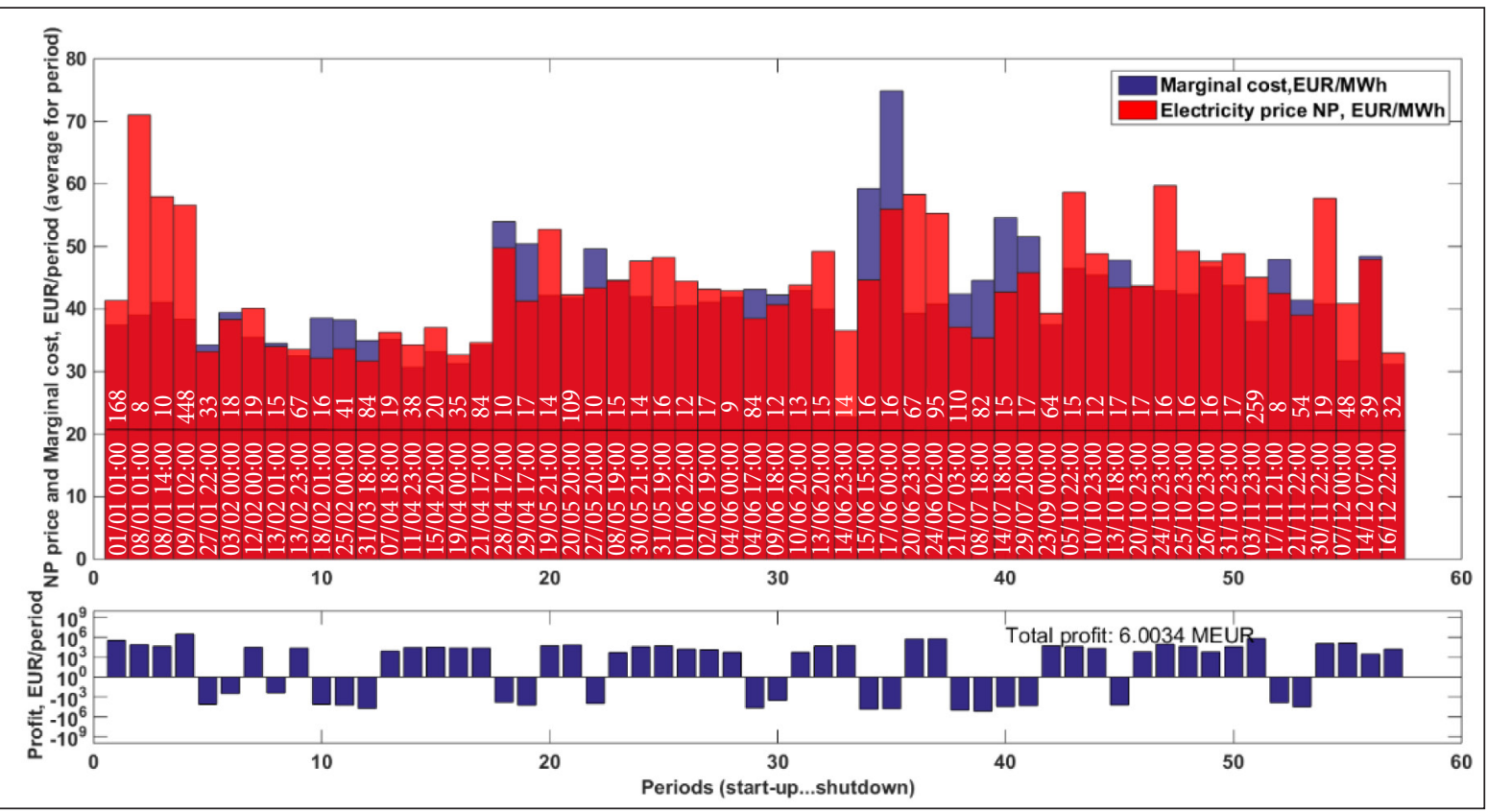

Fig. 10. Average Nord Pool price, average electricity marginal cost and profit from electricity realization in cycling operation ranges " $i$ "

Table 3. The results of optimization tasks

\begin{tabular}{c|cc|c|c|c|c|c}
\hline & $\begin{array}{c}\text { Profit, } \\
{[\mathrm{M} \in]}\end{array}$ & $\begin{array}{c}\Sigma i, \\
{[\text { [number] }}\end{array}$ & $\begin{array}{c}\text { Operation } \\
\text { hours, [h] }\end{array}$ & $\begin{array}{c}\text { Amount of hot } \\
\text { start-ups, [h] }\end{array}$ & $\begin{array}{c}\text { Amount of warm } \\
\text { start-ups, [h] }\end{array}$ & $\begin{array}{c}\text { Amount of cold } \\
\text { start-ups, [h] }\end{array}$ \\
\hline Before optimization & 6 & 57 & 2571 & 15 & 19 & 23 \\
\hline Optimization No. 1 $(\Pi \rightarrow \max )$ & 7.42 & 57 & 2799 & 21 & 15 & 21 \\
\hline Optimization No. 2 $(n \rightarrow$ max) & 7.27 & 53 & 2846 & 17 & 15 & 21 \\
\hline
\end{tabular}

cycling operation. The continuance of cycling operation ranges became longer, i.e. the blue solid line under the dash blue line or the shifting of blue dash line to the right is observed in Fig. 11. In turn, the duration of outages became rarer and shorter, i.e. mainly the red solid line is under

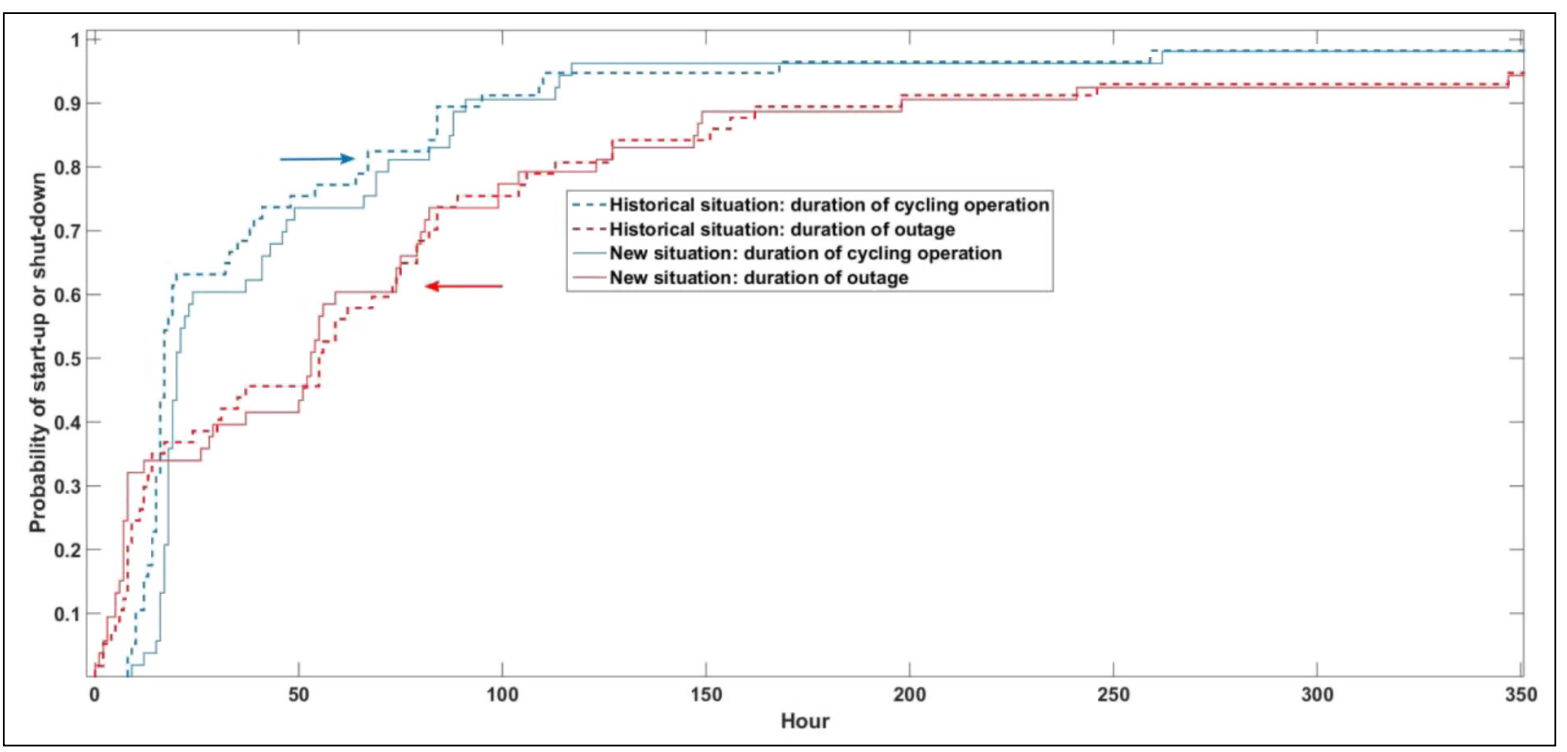

Fig. 11. Probability of start-ups and shutdowns before (historical situation) and after (new situation) Optimization №. 2 
the dash red line or the shifting of red dash line to the left is noticed in Fig. 11.

\section{DISCUSSIONS AND FUTURE WORK}

In this article, an approach has been developed for the combined cycle gas turbine power plant, which operates in the electricity market on the example of the Nord Pool intra-day physical market to ensure its operation in a more flexible, efficient and profitable way. The approach has been realized in a multi - paradigm numerical computing environment MATLab. The results from a real-life case study have shown that the developed approach is accurate and computationally efficient.

It is recommended to incorporate the developed approach in the generation portfolio of Riga CHP-2. The obtained results ensure that the use of this approach ensures the additional profit and the reduction of cycling operation negative impact on equipment technical resource (Optimization No. 2).

The presented concept of the developed approach can be adapted to various technology and physical markets by changing the characteristics and principles, respectively. It can be integrated into the unit commitment model and used as a corrective block for thermal power plants which take into account the features of cycling operation.

Directions for future research would include: (1) further improvement of the developed approach, e.g. time step minimization to the minute or second, the supplementation of the optimization model with the ramp rate of technology, heat load forecasting when the extension of the cycling operation range occurs; (2) the provision of numerical evidence that the achieved decrease of start-up numbers and the change of start-up types to the less adverse have the positive effect on a thermal power plant from an economical, technical and environmental point of view; (3) integration of the developed approach in the unit commitment model and making a conclusion on the usefulness of UC supplement with the developed approach.

Received 15 November 2017 Accepted 15 December 2017
References

1. Raezaie B., Rosen M. District heating and cooling: review of technology and potential enhancements. Applied Energy. 2012. Vol. 93. P. 2-10.

2. Lund H., Andersen A. N. Optimal designs of small CHP plants in a market with fluctuating electricity prices. Energy Conversion and Management. 2005. Vol. 46. Iss. 6. P. 893-904.

3. Linkevics O., Ivanova P., Balodis M. Electricity market liberalization and flexibility of conventional generation to balance intermittent renewable energy - is it possible to stay competitive? Latvian Journal of Physics and Technical Sciences. 2016. Vol. 53. Iss. 6. P. 47-56.

4. Benato P., Bracco S., Stoppato A., Mirandola A. Dynamic simulation of combined cycle power plant cycling in the electricity market. Energy Conversion and Management. 2016. Vol. 107. P. 76-85.

5. Zapata Riveros J., Bruninx K., Poncelet K., D'haeseleer W. Bidding strategies for virtual power plants considering CHPs and intermittent renewables. Energy Conversion and Management. 2015. Vol. 103. P. 408-418.

6. Bergh K., Delarue E. Cycling of conventional power plants: Technical limits and actual costs. Energy Conversions and Management. 2015. Vol. 97. P. 70-77.

7. Ludge S. The value of flexibility for fossil - fired power plants under the conditions of the Strommarkt 2.0. International Journal for Electricity and Heat Generation VGB Powertech. 2017. Iss. 3. P. 21-24. Available from: <https://www. vgb.org/vgbmultimedia/PT201703LUEDGE. pdf?bcsi_scan_67329b40c719e71c=akauSFKppi84mowqPR0HEO/NAc5KAAAA3R$8 \mathrm{OtQ}==\& \mathrm{bcsi}$ _s can_filen a me $=\mathrm{PT}$ 201703LUEDGE.pdf $>$ [07.05.2017]

8. Lund H., Andersen A., Ostergaard P., Mathiesen B., Connolly D. From electricity smart grids to smart energy systems - A market operation based approach and understanding. Energy. 2012. Vol. 42. P. 96-102.

9. Ivanova P., Sauhats A., Linkevics O., Balodis M. Combined heat and power plants towards efficient and flexible operation. Proceedings of IEEE 16th International Conference on Environmental and Electrical Engineering (EEEIC), June 7-10, 2016, Florence, Italy. P. 1-6. 
10. Wogrin S., Galbally D., Ramos A. CCGT unit commitment model with first-principle formulation of cycling costs due to fatigue damage. Energy. 2016. Vol. 113. P. 227-247.

11. Keatley P., Shibli A., Hewitt N. Estimating power plant start costs in cyclic operation. Applied Energy. 2013. Vol. 111. P. 550-557.

12. Dvorak M., Havel P. Combined heat and power production planning under liberalized market conditions. Applied Thermal Engineering. 2012. Vol. 43. P. 163-173.

13. Ravn H., Riisom J., Schaumburg-Muller C. A stochastic unit commitment model for a local CHP plant. Proceedings of 2005 IEEE Russia Power Tech, June 27-30, 2005, Petersburg, Russia. P. 1-7.

14. Illerhaus S., Verstege J. Optimal operation of industrial CHP-based power systems in liberalized energy market. Proceedings of PowerTech Budapest 99. International Conference on Electrical Power Engineering, August 29 - September 2, 1999, Budapest, Hungary. P. 1-6.

15. Silbernagl M., Huber M., Brandenberg R. Improving accuracy and efficiency of start-up cost formulations in MIP unit commitment by modelling power plant temperatures. IEEE Transactions on Power Systems. 2016. Vol. 31. Iss. 4. P. 2578-2586.

16. Tuffaha M., Tommy Gravdahl J. Mixed-integer formulation of unit commitment problem for power systems: Focus on start-up cost. Proceedings of 39rd Annual Conference of the IEEE Industrial Electronics Society (IECON), November 10-13, 2013, Vienna, Austria. P. 8160-8165.

17. Hubert M., Silbernagl M. Modeling start-up times in unit commitment by limiting temperature increase and heating. Proceedings of 12th International Conference on the European Energy Market (EEM), May 19-22, 2015, Lisbon, Portugal. P. 1-5.

18. Arroyo J. M., Conejo A. J. Modeling of start-up and shut-down power trajectories of thermal units. IEEE Transactions on Power Systems. 2004. Vol. 19. Iss. 3. P. 1562-1568.

19. Dimoulkas I., Amelin M. Constructing bidding curves for a CHP producer in day-ahead electricity market. Proceedings of IEEE International Energy Conference (ENERGYCON), May 13-14, 2014, Dubrovnik, Croatia. P. 487-494.
20. Aghaei J., Agelidis V., Charwand M., Heidari A. Optimal robust unit commitment of CHP plants in electricity markets using information gap decision theory. IEEE Transactions on Smart Grid. 2017. Vol. 8. Iss. 5. P. 2296-2304.

21. Albanesi C., Bossi M., Magni L., Paderno J., Pretolani F., Kuehl P., Diehl M. Optimization of the start-up procedure of a combined cycle power plant. Proceedings of the 45th IEEE Conference on Decision \& Control, December 13-15, 2006, San Diego, USA. P. 1840-1845.

22. Hellmers A., Zugno M., Skajaa A., Morales J. Operational strategies for a portfolio of wind farms and CHP plants in a two-price balancing market. IEEE Transactions on Power Systems. 2016. Vol. 31. Iss. 3. P. 2182-2191.

23. Zhou B., Geng G., Jiang Q. Hydro-thermal-wind coordination in day-ahead unit commitment. IEEE Transactions on Power Systems. 2016. Vol. 31. Iss. 6. P. 4626-4637.

24. Ivanova P., Sauhats A., Linkevics O. Towards optimization of combined cycle power plants' start-ups and shut-down. Proceedings of 57th International Scientific Conference on Power and Electrical Engineering of Riga Technical University (RTUCON 2016), October 13-14, 2016, Riga, Latvia. P. 1-6.

25. Ivanova P., Linkevics O., Sauhats A. Mathematical description of combined cycle gas turbine power plants' transient modes. Proceedings of IEEE International Conference on Environment and Electrical Engineering and IEEE Industrial and Commercial Power Systems Europe, June 6-9, 2017, Milan, Italy. P. 1-6.

26. Soysal E. R., Olsen O., Skytte K., Sekamane J. K. Intraday market asymmetries - a Nordic example. Proceedings of 14th International Conference on the European Energy Market, June 6-9, 2017, Dresden, Germany. P. 1-6.

27. About Nord Pool power market. Available from: <http://www.nordpoolspot.com/the-power-market/> [30.09.2017]

28. Abobaid F., Postler R., Strohle J., Epple B., HyunGee K. Modeling and investigation start-up procedures of a combined cycle power plant. Applied Energy. 2008. Vol. 85. P. 1173-1189.

29. Benato A., Stoppato A., Bracco S. Combined cycle power plants: A comparison between two 
different dynamic model to evaluate transient behaviour and residual life. Energy Conversion and Management. 2014. Vol. 87. P. 1269-1280.

30. Kunickis M., Balodis M., Sarma U., Cers A., Linkevics O. Efficient use of cogeneration and fuel diversification. Latvian Journal of Physics and Technical Sciences. 2015. Iss. 6. P. 38-48.

Polina Ivanova, Ervin Grebesh, Anna Mutule, Olegs Linkevics

CIKLINIO EKSPLOATAVIMO OPTIMIZAVIMO METODAS TRADICINĖMS KOGENERACINĖMS JĖGAINE்MS

\section{Santrauka}

Rinkos mechanizmų igyvendinimas, apimantis elektros energijos kainų svyravimus ir plataus atsinaujinančių energijos išteklių (saulès ir vejjo energijos) integravimą i elektros energijos gamybą, pakeitè tradicinès energijos gamybos vaidmenị ir veikimą. Tai iš dalies arba iš viso nèra pritaikyta naujoms eksploatavimo sąlygoms, todèl reikia tobulinti tradicinès elektros gamybos efektyvumą ir lankstumą. Kombinuotojo ciklo dujų turbinų (angl. CCGT) technologijų pagrindu sukurtas skaitmeninis metodas siekiant pritaikyti jų veikimo sąlygas elektros energijos rinkai. Sukurtas metodas buvo patvirtintas MATLab skaičiavimo aplinkoje Baltijos šalių (Latvijos) atvejo analize. Gauti rezultatai rodo, kad papildomas pelnas yra gaunamas gaminant daugiau elektros energijos, o ciklinès eksploatacijos poveikis sumažeja mažinant ciklų skaičių ir pakeičiant paleidimus palankesniu techniniu ir ekonominiu režimu. Sukurtas metodas gali būti pritaikytas ịvairioms technologijoms ir situacijoms papildant atitinkamas technologines charakteristikas ir ribojimus.

Raktažodžiai: tradicinè gamyba, ciklinè eksploatacija, elektros rinka, paleidimas, stabdymas 